\title{
CORPORATE SOCIAL RESPONSIBILITY: A PHARMACEUTICAL INDUSTRY ANALYSIS
}

\author{
DJ Theron (University of Johannesburg)
}

\begin{abstract}
In the modern business environment organisations need to address two important aspects affecting their operations: the quality of management and the impact of their operations on the well-being of the society in which they operate. This dualism often results in economic, political and social dilemmas influencing the viability of organisations in general, and more specifically and recently, local and international pharmaceutical organisations operating in South Africa. This article considers the aspect of corporate social responsibility (CSR) in general and attempts to identify the social-related issues impacting on the pharmaceutical industry by means of content analysis - a research technique for making replicable and valid inferences from data. It furthermore describes the re-action of pharmaceutical organisations when confronted with such social demands, and finally analyses the management of CSR against four criteria of CSR. The article confirms the importance of managers to manage CSR towards society in a proactive manner. It furthermore suggests that the "hard" factors of strategic management and financial performance should be balanced with "soft" social/people issues. It also recommends that the industry should consider - and if applicable - endorse the concept of Issues Management as an approach to the proactive management of CSR.
\end{abstract}

Key phrases: content analysis, the pharmaceutical industry, corporate social responsibility, corporate social responsibility management, social-related issues, responses to social demands, issues management

\section{INTRODUCTION}

In recent years social pressure from government and Non Governmental Organisations (NGOs) have been mounting against pharmaceutical organisations operating in South Africa. There is, for instance, a public outcry for lower prices of medicines in general and increasing governmental pressure for affordable treatment of the so-called social responsibility diseases of HIV/AIDS, tuberculosis and malaria. The pharmaceutical industry in South Africa has as a consequence of this insistence become a complicated, stressful industry having to satisfy the demands of competitive international markets while simultaneously having to deal with increasing social needs and government intervention to provide affordable health-care to all South African citizens.

\section{THEORETICAL BACKGROUND}

The idea of sustainability, that is, how organisations balance economic, environmental, and social issues is not new. Although social issues are often reported in the popular press (Anon a, 2003:62; Anon b, 2003:7; Anon c, 2003:12; Bonorchis, 2004:2; Keeton, 2003:16; Webster, 2003:7) and professional publications (Ludman, 2003:83-90; Naidoo, 2003:89-91; Pellissier, 2004:25), the management of corporate social responsibility by pharmaceutical organisations has received scant attention from South African researchers.

\section{THE PURPOSE OF THE ARTICLE}

In view of the lack of South African data on the management of Corporate Social Responsibility (CSR) in the pharmaceutical industry, the intent of this article is to explore emergent and current socialrelated demands impacting on the pharmaceutical industry and to analyse responses to, and the management of CSR in relation to these demands. 


\section{CORPORATE SOCIAL RESPONSIBILITY}

Various authors (Anon d, 2003:17; Baker, 2004:36; Daft 2000:143; Hilton \& Gibbons 2002:65; Juholin, 2004:54; O'Dwyer 2003:22; Weiss 2003:53; Weymes, 2004:14) have defined CSR. Implicit herein is an awareness that CSR is about how organisations manage business processes to produce an overall positive impact on society. It means distinguishing right from wrong and being a good corporate citizen.

Ehlers and Lazenby (2004:44) list three more reasons why it is important for strategists to consider social responsibility when formulating strategies, namely:

- An organisation's right to exist depends on its environment and society.

- National legislation threatens increased regulation if organisations do not meet changing social standards.

- A responsive corporate policy may enhance an organisation's long-term profitability and sustainability.

Although Weiss (2003:53-61) does not explicitly address the management of CSR the author suggests a stakeholder approach when formulating strategies to manage one of the components of CSR namely business ethics. The primary stakeholders of the pharmaceutical industry are the investors, shareholders, employees, customers, and suppliers. Secondary stakeholders include, amongst others, government and society. Primary and secondary stakeholders have different beliefs as to which actions improve society's welfare. To complicate matters, social responsibility can cover a range of issues, many of which are ambiguous with respect to right or wrong. Another difficulty in understanding social responsibility is that managers must confront the question "responsibility to which stakeholder?" as stakeholders may each have different criterion of responsiveness because of different interests in an organisation.

Although management scholars such as Weiss (2003:53-69) and Wheelen \& Hunger (2004) describe the characteristics of socially responsible organisations, the question also arises: "When confronted with different social demands from a variety of stakeholders; how might an organisation respond?" Daft (2000:177-179) describes four possible corporate response actions towards social demands:

\section{Corporate Actions towards Social Demands}

Response actions could according to Daft (2000:177-179), be classified as obstructive, defensive, accommodative, or proactive.

\section{Obstructive responses}

Organisations that adopt obstructive responses deny all responsibility, claim that evidence of wrongdoing is misleading or distorted, and place obstacles to delay investigation. A. H. Robins Company, for example, reportedly used obstructive actions when it received warnings about the use of its "Dalkon Shield", an intrauterine device. The organisation built a wall around itself. It stood against all evidence and insisted that the product was safe and effective. The organisation spared no effort to resist investigation and destroyed all papers pertaining to the product. More recently, during lawsuits against the tobacco industry in the USA, organisations were accused of using obstructive measures by hiding the facts of their own research indicating the possible health hazards of smoking.

\section{Defensive responses}

With a defensive response, the organisation admits to some errors of commission or omission. The 
organisation cuts its losses by defending itself but without acting obstructively. For example, activists often accuse multinational pharmaceutical organisations of profiting from social diseases. In response, organisations often argue that, if producing new and innovative medicines is as cheap as activists claim, such activists should be able to produce the drugs themselves. They often also insist that activists drop their misguided attacks on their private and intellectual property. In South Africa, for example, the SA Pharmaceutical Manufacturer's Association chose a defensive approach towards pending healthcare regulations in 2004 and by doing so delayed the changes in health care legislation as proposed by the Ministry of Health.

\section{Accommodative responses}

An accommodative response means that the organisation accepts social responsibility for its actions, although it may do so in response to external pressure. Organisations that adopt this action try to meet economic, legal, and ethical responsibilities. If outside forces apply pressure, managers agree to curtail ethically questionable activities. Organisations will often hire an ethical consultant to help them clean up their act and improve their public image. Bristol Myers Squibb has, for instance, dropped a patent dispute with an AIDS patient in Thailand, stating that it would dedicate the patent for the drug, Didanosine, to the people of Thailand - an accommodative decision based largely on public outcry.

\section{Proactive responses}

Organisations that adopt a proactive response take the lead in social issues. They seek to learn what is in the public interest and respond without coaxing or pressure from stakeholders. Potlatch Corporation in the USA for example, printed photographs of missing children on their milk cartons. Contrary to their defensive actions in Thailand, Bristol Myers Squibb has recently expanded its philanthropic "Secure the Future" program by pledging an additional $\$ 15$ million and thereby raising its total level of social commitment to $\$ 115$ million. This will allow it to continue developing innovative ways to prevent and treat HIV/AIDS in African countries. In South Africa Aspen Pharmacare, Africa's biggest manufacturer of generic medicines recently (January 2005) became the first company to obtain US Food and Drug Administration approval for its generic AIDS medicines. FDA approval opens the way for Aspen to benefit from the \$15bn US President's Emergency Plan for AIDS relief.

\section{EVALUATING CORPORATE SOCIAL RESPONSIBILITY MANAGEMENT}

Authors such as Benioff (2004:85-88) and Weiss (2003:149-162) describe ways to measure the impact of philanthropy and social return on investments. Although there is no method yet to empirically evaluate management of CSR, Daft (2000:1777-179) and Wheelen \& Hunger (2004:4953) have described the following four general criteria that could influence the effectiveness of CSR management:

\section{The Management of Economic Responsibilities}

The first criterion is economic responsibility. Profits are after all the major reason for an organisation's existence and the business institution is, above all, the basic economic unit of society. Its responsibility is to produce goods and services needed by society and to maximise profits for its owners and shareholders. The management of this criterion carried to the extreme is called the profitmaximising view advocated by Nobel economist Milton Friedman. This approach implies that economic gain is the organisation's only social responsibility. This view is no longer considered as the only criterion because of corporate economic performance becoming inextricably linked to social issues and demands. The recent South African business failure of MacMed Pharmaceuticals supports the shift away from pure financial performance to good governance and the socially acceptable behaviour of management. 


\section{The Management of Political/Legal Responsibilities}

All modern societies lay down ground rules, laws, and regulations that organisations are expected to follow. Political/legal responsibility defines what society deems as important with respect to appropriate corporate behaviour. Organisations are expected to fulfil their economic goals within a legal framework of state legislators that are becoming increasingly imposing. At present, the entire health care industry in South Africa is going through major changes because of recently imposed and possible new legal requirements and the insistence of government that the industry should operate within laid down legal parameters.

\section{The Management of Ethical Responsibilities}

Ethical responsibility includes behaviours that are not necessarily codified into law and may not serve the organisation's direct economic interests. To be ethical, organisation decision-makers should act with equity, fairness and impartiality, as well as respecting the rights of individuals. Managing in an unethical manner occurs when decisions enable an organisation to gain at the expense of workers and society. One area that has recently been called into question concerns Internet sites for children set up by organisations such as Kellogg and Nabisco. Watchdog groups charge that these organisations were acting unethically by using games and other forms of entertainment designed to gather marketing data from children as young as four years old. Apart from a few exceptions, pharmaceutical organisations trading in South Africa take pride in their good corporate governance and high moral and ethical business standards.

\section{The Management of Discretionary Responsibilities}

Discretionary responsibility is purely voluntary and guided by an organisation's desire to make social contributions not mandated by economics, law, or ethics. Discretionary activities include generous philanthropic contributions that offer no payback to the organisation and are not expected. An example of discretionary behaviour occurred when Yskor (renamed Ispatisc) helped laid-off steelworkers by establishing re-training facilities in the Vanderbijlpark area. The management of discretionary responsibility is the highest criterion of CSR because it goes beyond societal expectations to contribute to the welfare of communities.

\section{PROBLEM STATEMENT AND OBJECTIVES}

In view of the aforementioned discussion, it is evident that organisations and managers often walk a fine line in their efforts to do the right thing, that is, to be profitable and simultaneously satisfy the needs of its numerous stakeholders. Three questions could be asked with regard to pharmaceutical organisations operating in South Africa, namely:

- What are the main social-related issues affecting pharmaceutical organisations?

- How do these organisations act when confronted with these social demands?

- What importance do managers attach to CSR criteria?

In order to address these questions four objectives were set, namely:

- To identify the current social-related issues affecting pharmaceutical organisations operating in South Africa.

- To list examples of obstructive, defensive, accommodative and proactive responses of pharmaceutical organisations operating in South Africa. 
- To compare the different corporate response actions when confronted with specific social demands.

- To measure the comparative frequencies of economic, political/legal, ethical, and discretionary CSR criteria with specific social-related issues.

\section{RESEARCH DESIGN}

The research was designed as an exploratory study in order to make certain observations and quantitative analysis of messages by means of the scientific method of content analysis.

\section{Content Analysis}

Content analysis was selected as the appropriate instrument of exploratory research. It has been described as perhaps the fastest-growing technique in quantitative research and involves the selection of certain key words or phrases, counting and analysing the frequencies of such key phrases or words in the body of information. Neuendorf (2002:1) defines content analysis as the systematic, objective, quantitative analysis of message characteristics. It includes the careful examination of human interactions; the analysis of character portrayals in TV commercials, films, and novels; the computer-driven investigation of word usage in news releases and political speeches; and so much more. Welman \& Kruger 1999:201) describe content analysis as a special application of systematic observation that involves the contents of sources being examined in order to record the relative incidence (frequencies) of themes and of the ways in which these themes are portrayed. According to Emory \& Cooper (1991:457) content analysis measures the semantic content or the "what" aspect of a message. Its breadth makes it a flexible and wide-ranging tool that may be used as a methodology or as a problem-specific technique. McDonnell (1986:566-571) states that content analysis is not a fixed analytical technique but rather an approach that offers guidelines for a systematic analysis of written communications. From the above it can be concluded that content analysis is a summarising, quantitative analysis of messages that relies on a scientific method, including a priori research design, an orderly method and a systematic analysis of content.

\section{Methodology}

Content analysis is a research method that uses a set of procedures for making valid inferences from information. The methodology therefore involves the gathering of information, and the reporting and analysis of researched data.

\section{Gathering of information}

The gathering of information through content analysis requires a definition of the universe of appropriate media. The printed media and the Internet were demarcated as the relevant sample frame. As content analysis examines content that appears at various times, and as communication in the media occurs on an ongoing and often regular basis (Riffe, Lacy \& Fico 1998:99) the gathering of information was done over a period of 12 months between January and December 2004. The printed media was accessed with the aid of the Proquest, Emerald, Nexus, SA media and SA studies electronic databases of the University of Johannesburg. Comments and articles in printed circulars and journals of pharmacy organisations such as the SA Pharmacy Council, the SA Pharmaceutical Society, the National Pharmaceutical Wholesaler Association, and the SA Pharmaceutical Manufacturer's Association (as well as the annual reports of pharmaceutical organisations - as a reflection of critical management issues) provided a further insightful source of data.

In addition to the printed media, the Internet can be used as a means of dividing up message contexts. According to Neuendorf (2002:22) the Internet transcends the distinctions of interpersonal, group, and mass communication. The Internet was therefore used as a valuable source of information. Furthermore, the URLs, which normally include organisational reports and other related 
Internet sights of pharmaceutical organisations were regarded as informative and therefore used in this study. There are currently sixty manufacturing and fourty international agencies operating in South Africa and registered with the SA Pharmacy Council. The contents of the URLs of all these organisations were accessed and explored for data relevant to this article.

\section{Results}

The data collated from the Internet and printed media by means of a content analysis are summarised in Tables $1-3$ and furthermore illustrated in Figures $1 \& 2$.

\section{TABLE 1}

\section{EXAMPLES OF EMERGENT AND CURRENT SOCIAL-RELATED ISSUES IMPACTING ON} PHARMACEUTICAL ORGANISATIONS

\section{Economic issues}

- Prescriptiveness of authorities to control the industry.

- Single exit prices on medicines to control medicine prices.

- Diminishing returns on pharmaceutical investments.

- The operating environment becoming less free market orientated.

Political/legal issues

- Legislation to make healthcare providers more accessible.

- Black empowerment to comply with BEE legislation.

- Employment equity for workers.

Ethical issues

- Generic medicine substitution in order to lower costs.

- Managed health care to render health care more effective.

- The need to develop life saving vs. profitable medicines.

- Transparency on medicine pricing to curb immoral incentives.

Discretionary issues

- Prioritising social-related issues instead of economic criteria.

- Emphasis on social responsibility diseases of HIV/AIDS, tuberculosis and malaria.

Table 1 confirms the emerging and current social-related issues impacting on the pharmaceutical industry. The observation leads one to believe that economic, political/legal and ethical issues, with concomitant governmental regulation and control remain the dominant themes. For the industry such pressures conjure up images of change and high levels of uncertainty.

\section{TABLE 2}

\section{EXAMPLES OF RESPONSE ACTIONS TOWARDS SOCIAL DEMANDS}

\section{Obstructive responses}

- Threats of pharmaceutical organisations to withdraw investments from South Africa.

- Threats to institute proceedings against the Ministry of Health.

- Drug laws being described as "draconian".

- Directors predicting times of great upheaval and uncertainty.

- Organisations strongly opposing the implementation of new health care legislation.

- Money spent on CSR being described as theft of shareholders money. 
Table 2 continuous:

\section{Defensive responses}

- Impending legislation will force organisations out of business.

- Action by government will have a material adverse impact on organisations in future.

- Legislation changes in the health care landscape will create uncertainty.

- Organisations rejecting the charge that medicine prices are excessive.

- Organisations not being responsible when patients voluntarily misuse their products.

Accommodative responses

- Organisations will support and align themselves with the aims of the government.

- Pharmaceutical organisations will build partnerships with government.

- Organisations will accept the challenge of new changes.

- Organisations will strive to make health-care more affordable.

- Predictions that imminent changes are unlikely to have a material adverse impact on pharmaceutical organisations.

- Expressions of support for the initiatives of the Ministry of Health.

- Opinions that an agreement between pharmaceutical organisations and the Ministry of Health must be reached on new prices of medicines.

Proactive responses

- The industry having a vision with regard to social responsibility, and organisations expressing a commitment to social responsibility programmes.

- Objectives of best possible standards of health care at affordable prices.

- Endorsements of moving towards international standards.

- Schools of excellence that will offer value-added training to medical and pharmaceutical providers.

- Organisations identifying learning needs and developing the capacity of employees.

- Commitment to innovation and change.

- Establishing an international pricing benchmark for medicines in 2005.

- The transfer of global technology to SA organisations to combat social diseases.

- Commitment to corporate social investment and CSR.

Table 2 confirms examples of obstructive, defensive, accommodative, and proactive CSR response actions within the pharmaceutical industry. The distribution of these responses in relation to each social-related public issue is presented in Table 3.

\section{Analysis of the data}

Table 3 presents an analysis of CSR response actions (Internet \& print frequencies) in relation to emergent and current social-related issues and Figure 1 graphically illustrates these relationships in the format of a radar chart.

TABLE 3

COMPARATIVE FREQUENCIES OF RESPONSE ACTIONS

\begin{tabular}{|c|c|c|c|c|c|c|c|c|}
\hline \multirow{2}{*}{$\begin{array}{c}\text { SOCIAL-RELATED } \\
\text { PUBLIC ISSUES }\end{array}$} & \multicolumn{10}{|c|}{ RESPONSE ACTIONS } \\
\cline { 2 - 12 } & Obstructive & \multicolumn{2}{|c|}{ Defensive } & \multicolumn{2}{c|}{ Accomodative } & \multicolumn{2}{c|}{ Proactive } \\
\cline { 2 - 11 } & $\begin{array}{c}\text { Net } \\
\text { freq }\end{array}$ & $\begin{array}{l}\text { Print } \\
\text { Freq }\end{array}$ & $\begin{array}{l}\text { Net } \\
\text { Freq }\end{array}$ & $\begin{array}{l}\text { Print } \\
\text { Freq }\end{array}$ & $\begin{array}{l}\text { Net } \\
\text { Freq }\end{array}$ & $\begin{array}{l}\text { Print } \\
\text { Freq }\end{array}$ & $\begin{array}{l}\text { Net } \\
\text { Freq }\end{array}$ & $\begin{array}{c}\text { Print } \\
\text { Freq }\end{array}$ \\
\hline Economic issues & 13 & 36 & 10 & 29 & 8 & 24 & 9 & 11 \\
\hline Political/legal Issues & 5 & 27 & 7 & 21 & 9 & 16 & 5 & 8 \\
\hline Ethical issues & 1 & 4 & 5 & 9 & 5 & 16 & 4 & 6 \\
\hline Discretionary issues & 2 & 2 & 1 & 2 & 4 & 9 & 3 & 4 \\
\hline
\end{tabular}




\section{FIGURE 1 \\ GRAPHICAL DISPARITIES BETWEEN RESPONSE ACTIONS}

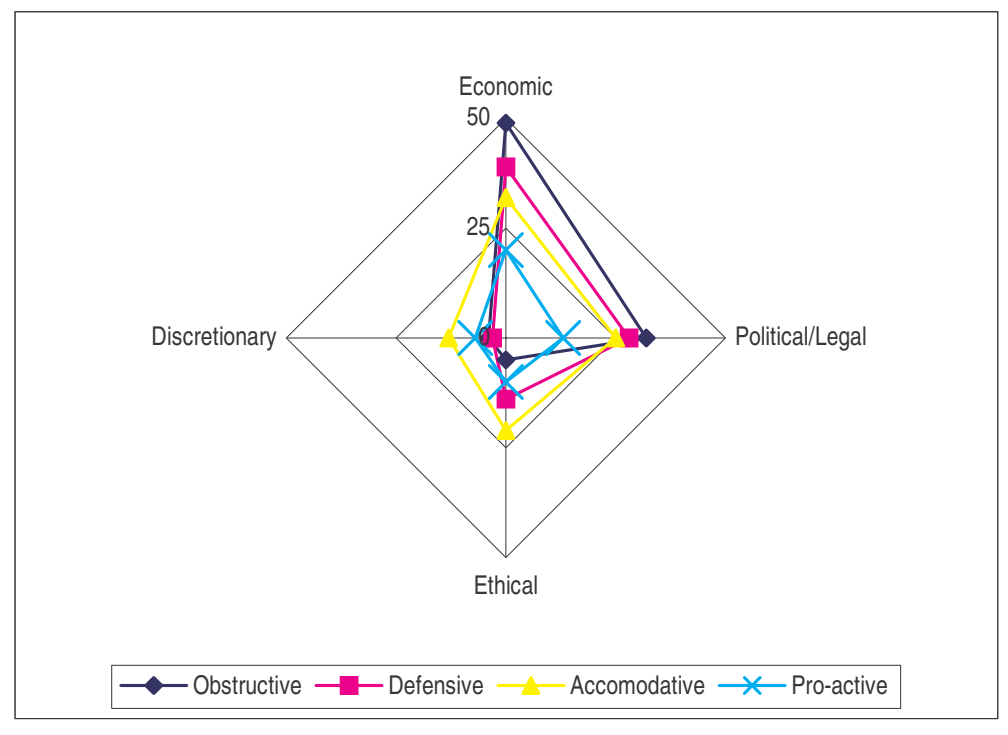

From Figure 1 it is clear that the profile dominates the economic and political/legal environmental dimensions. The interpretation is that there is evidence of strong obstructive and defensive behaviour within the industry against economic, political and legal interference. In this regard pharmaceutical organisations complain that impending legislation will force them out of business with some international organisations clandestinely threatening to withdraw from South Africa. Bodies representing the industry are furthermore challenging regulations that sought to control factory exit price of medicines. Paradoxically, a reasonably high accommodative response exists within the industry with organisations being prepared to align themselves with the aims of the government. There seems to be a lower emphasis on proactive responses of having a vision with regards to an organisation's social responsibilities and its responsibility towards social diseases.

Figure 2 graphically illustrates the emphasis on the different CSR responsibility criteria (Internet \& print frequencies) as derived from Table 3 , in the format of a bar chart.

\section{FIGURE 2 \\ GRAPHICAL DISPARITIES BETWEEN CSR RESPONSIBILITY CRITERIA}

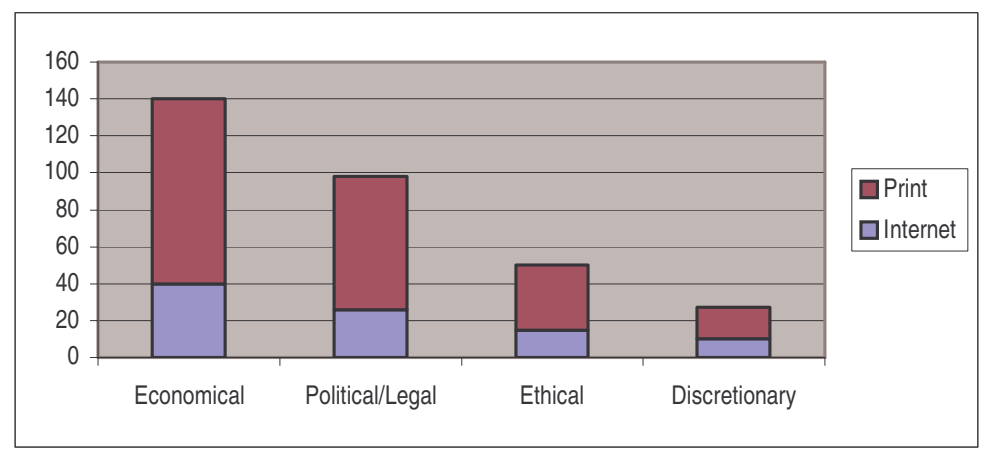


From Figure 2 the dominance of economic and political/legal criteria is evident. This emphasis implies that economic gain is regarded as an important social responsibility with regard to stakeholders within the pharmaceutical industry. The emphasis on political/legal responsibility seems to indicate the importance of beneficial relations with the state and of fulfilling economic goals within a legal framework of state legislators. Figure 2 also illustrates the lesser importance of ethical and discretionary criteria and consequently, an opportunity for increased socially acceptable behaviour by pharmaceutical organisations.

\section{DISCUSSION}

Implicit in the results of this exploratory study is the belief that managers of pharmaceutical organisations operating in South Africa are alert to a number of social-related public issues affecting the viability of their organisations. Special significance is attached to the issues of impending legislation to curb the cost of medicines and to secure affordable medication for the treatment of social responsibility diseases.

Confronted with these political/legal and ethical demands there is, however, a display of obstructive behaviour in the industry with, for example, the Pharmaceutical Society and New Clicks instituting legal proceedings against the Ministry of Health to stop further impending health care legislation. This action is supported by a strong defensive motivation that the proposed legislation will adversely impact on the industry in general and that the economic issue of controlled prices and dispensing fees will force up to fifty percent of retail pharmacies out of business. The industry, however, seems to be accommodative by aligning itself with the aim of the Minister of Health to make health-care more affordable in South Africa. In this regard the industry is prepared to build partnerships with government; to be supportive of the SA National Health Policy; and to be instrumental in securing affordable medication for the treatment of social responsibility diseases. Although such actions could be viewed as proactive, they are indicative of the obstructive and defensive re-active management tendencies of directors as opposed to their management of the social-related issues impacting on their organisations in a proactive manner. Due to: the fact that the aim of strategic planning is to proactively formulate plans to achieve the objectives of the organisation; the fact that strategic planning together with strategy implementation gives rise to strategic management; and the a lack of proactive management of social-related issues impacting on the industry, it could be concluded that an impediment exists with regards to strategically managing CSR in pharmaceutical organisations. This argument is supported by the analysis of comparative frequencies of CSR responsibilities as illustrated in Figure 2, indicating a low emphasis on purely voluntary and proactive actions by management.

\section{CONCLUSION}

The study demarcated in this article seems to indicate that the "hard" factors of strategic management and financial performance should be balanced with "soft" social/people issues. Greater awareness of social responsibility and good citizenship coincides with the year in which South Africa celebrated its $10^{\text {th }}$ year of democracy. In this new era of optimism, success and growth the pharmaceutical industry needs to be value driven by organisations always acting in the best interest of their customers, communities, employees, and shareholders. Pharmaceutical organisations consequently need to be governed in a manner that upholds the expectations of all stakeholders. Forming alliances, having a social purpose, and coming to an understanding with government on social related issues will remain important. Doing business and being socially responsible must consequently be regarded as two sides of the same coin, possibly keeping in mind the maxim of Pick ' $n$ Pay that "Doing good is good business."

This article furthermore confirms that the pharmaceutical industry is balancing precariously on the edge of the proverbial cliff, caught between the comfortable habits and known territories of the past, and the foreign waters and unknown currents of the future. Apart from managing their profits in this turbulent sea, pharmaceutical organisations operating in South Africa will also need to manage their

\section{Acta Commercii 2005 Volume 5}


corporate responsibilities towards society proactively. Time does not stand still, and change in South Africa, as elsewhere, is inescapable - the industry will have to change radically. Individual managers and the organisations they work for cannot afford to be neutral on the question of social change and their responsibilities in this regard. Strategic fit means actively striving to align the organisation's internal policies - including policies with regard to the management of CSR - with its day-to-day decisions and actions. It means aligning its resources - people, money, materials and technology with its core purpose, taking into account the interplay of both internal and external demands.

\section{RECOMMENDATION}

For the pharmaceutical industry the management of CSR will require more than merely an adaptation to changes in health care legislation or an effort to find a compromise with governmental agencies and pressure groups regarding ethical issues. It will demand social investment programmes that are flexible, empathetic and responsive to the changing needs of communities. It would furthermore require the management of social-related issues in a proactive manner as the current efforts of the industry can be viewed more as a reaction to social demands, than a proactive management strategy to manage the issues. In this respect it is recommended that the industry should consider - and if applicable - endorse the concept of Issues Management as an approach to the proactive management of CSR.

Previous studies (Ansoff 1980:131-148; Arrington \& Sawaya 1984:17-24; Coates, Jarratt \& Heinz 1986:46-59; Ewing 1987:23-47; and Theron 1996) have provided various theories regarding Issues Management. More recently Weiss (2003:53-61) explored Issues Management as an approach to business ethics, the latter being one of the components of CSR. The basic model provides a proactive means to identify emerging public issues in a rapidly changing business environment. It is also portrayed as an effective management tool to manage emerging issues timeously before they become costly crises issues in the public domain. Weiss (2003:53-61) furthermore proposes three general issues frameworks for mapping and managing moral issues before and even after they become crises for organisations. Although these frameworks validate Issues Management from a business ethics perspective, Issues Management also seems to have the potential to - in the larger domain of CSR - provide a means to detect and manage social-related issues, thereby enhancing effective and proactive CSR management in organisations.

\section{SUGGESTIONS FOR FURTHER RESEARCH}

This article indicates certain areas that could be further investigated, namely:

- An assessment of CSR in national and international pharmaceutical organisations operating in Africa. This could include demonstrable commitments against benchmarks such as pricing; patents; joint private initiatives; research \& development; and the appropriate use of medicines.

- An empirical evaluation of the effectiveness of CSR management in the pharmaceutical industry in South Africa.

- The extent to which Issues Management can enhance proactive CSR management and recommending a framework for implementing such a management process.

\section{REFERENCES}

Anon a. 2003. GSK helps to change lives through ARV access programme. Time, 8 Dec:62.

Anon b. 2003. Working with key players is vital for projects to succeed. Business Day, 7 Feb:7. 
Anon c. 2003. Free anti-fungal drug for people with aids. The Star, 12 Sept:12.

Anon d. 2003. The business world's latest buzzword? CSR and what it means to you. Strategic Direction ; 19 (6):17.

Ansoff HI. 1980; Strategic issue management. Strategic Management Journal, 1(2):131 -148.

Arrington CB \& Sawaya RN. 1984. Issues Management in an uncertain environment. Long Range Planning, 17(6): 17-24.

Baker RL. 2004. Management. $5^{\text {th }}$ Ed. NY USA: Dryden Press.

Benioff M. 2004. Compassionate capitalism: how corporations can make good an integral part of doing well. NJ USA: Career Press.

Bonorchis R. 2004. The wealth and weight of the social responsibility index. The Star, 7 Oct :2.

Coates JF, Jarratt J \& Heinz L. 1986. Issues management: how to plan, organize and manage for the future. Mount Airy USA: Lomond.

Daft RL. 2000. Management. Fifth ed. NY USA: Dryden Press.

Ehlers T \& Lazenby K. 2004. Strategic Management. Pretoria RSA: Van Schaik.

Emory CW \& Cooper DR. 1991. Business Research Methods. $4^{\text {th }}$ Ed. Boston USA: Homewood: Irwin.

Ewing RP. 1987. Managing the new bottom line: issues management for senior executives. Homewood USA: Irwin.

Hilton S \& Gibbons G. 2002. Good business: your world needs you. London UK: Texere.

Juholin E. 2004. For business or the good of all? A Finnish approach to corporate social responsibility. Corporate Governance: International Journal of Business in Society. 4(3).

Keeton C. 2003. Big Business. Leadership SA, May:16.

Ludman B. 2003. Corporate social responsibility: special report. Financial Mail Special Report, (173) 7: $83-90$.

McDonnell D. 1986. The president's letter to stockholders: a new look. Financial Analysts Journal, 9(3): $566-71$.

Naidoo RAJ. 2003; Towards sustainable drug development: Pharma R\&D drug development. Pharmaceutical \& Cosmetic Review, (30) 3:89-91.

Neuendorf KA. 2002. The Content Analysis Guidebook. Thousand Oaks, California: Sage Publications.

O'Dwyer B. 2002. Conceptions of corporate social responsibility: the nature of managerial capture. Accounting, Auditing, (16) 4:22.

Pellissier R. 2004. Leadership as a social responsibility: inside the business schools. Professional Management Review, March:25 
Riffe D, Lacy A \& Fico FG. 1998. Analysing media messages : using quantitative content analysis in research. N.J USA: Erlbaum.

Theron DJ. 1996. Issues management: a strategy to manage proactive change in South African Universities. Unpublished DComm thesis. Johannesburg RSA: RAU.

Webster C. 2003. Focus on social investment - The pharmaceutical industry: Industry has a responsibility to community. Business Day, 7 Feb:7.

Weiss JW. 2003. Business ethics: a stakeholder and issues management approach. Ohio USA: Mason.

Welman JC \& Kruger SJ. 1999. Research methodology for the business and administrative sciences. Johannesburg : Thomson.

Weymes Ed. 2004. A challenge to traditional management theory. Foresight - The journal of future studies, strategic thinking and policy, 6(6):14.

Wheelen TL \& Hunger DJ. 2004. Strategic management and business policy. NJ USA: Prentice Hall.

URL's of organisational websites evaluated for the purpose of the study as demarcated in this article. [Accessed: 2004, January - December]

\author{
http://www.3M.com \\ http://www.abbott.com \\ http://www.adcock.co.za \\ http://www.alclin.co.za \\ http://www.alcon.com \\ http://www.alliancepharma.co.za \\ http://www.allergan.com \\ http://www.asrazeneca.co.za \\ http://www.aventis.co.za \\ http://www.bayer.com \\ http://www.biomox.com \\ http://www.boehringer.com \\ http://www.bristolmeyerssquib.com \\ http://www.doh.gov.za
}

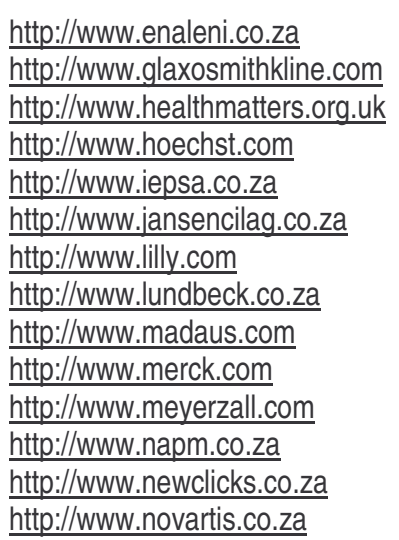

http://www.enaleni.co.za

http://www.glaxosmithkline.com

http://www.hoechst.com

http://www.iepsa.co.za

http://www.jansencilag.co.za

http://www.lilly.com

http://www.lundbeck.co.za

http://www.madaus.com

http://www.merck.com

http://www.novartis.co.za

\author{
http://www.novo.co.za \\ http://www.pfizer.com \\ http://www.pharmacare.co.za \\ http://www.ranbaxy.com \\ http://www.roche.co.za \\ http://www.responsiblepractice.com \\ http://www.sandoz.com \\ http://www.sapharmcouncil.co.za \\ http://www.savethechildren.org.uk \\ http://www.schering.com \\ http://www.serevac.co.za \\ http://www.stiefel.com \\ http://www.wyeth.com \\ http://www.yamanouchi.com
}

